\title{
Interculturalism in Sam Najjair's account of the battle for Tripoli: Soldier for a Summer
}

\author{
Marie-Violaine Louvet \\ Toulouse 1 - Capitole University, France
}

Copyright (c) 2016 by Marie-Violaine Louvet. This text may be archived and redistributed both in electronic form and in hard copy, provided that the author and journal are properly cited and no fee is charged for access.

\begin{abstract}
Interculturalism is the result of an interaction between different cultures and the possibility of the emergence of a new form of cultural expression and identity. This article studies the process of conciliation or re-conciliation of two cultures in Sam Najjair's book Soldier for a Summer. This is the diary of an Irish Libyan citizen who participated in the liberation of Tripoli from Gaddafi's rule in the Summer of 2011, during the Libyan civil war. The reader follows the main character from Dublin to Tripoli and then back to Dublin at the end of the war. In the book, which is first and foremost targeted at the Irish public to try to gather support for the revolution, Sam Najjair outlines an intercultural space between Ireland and Libya, opening 'an Irish angle' on the Libyan conflict, directly connected to his dual identity of a Libyan second generation immigrant living in Ireland.
\end{abstract}

Key Words. Ireland, Libya, Interculturalism, Autobiography, Tripoli Brigade, Sam Najjair.

Resumen. La interculturalidad es el resultado de una interacción entre diferentes culturas y la posibilidad de la aparición de una nueva forma de expresión e identidad cultural. En este artículo se estudia el proceso de conciliación o re-conciliación de dos culturas en Los leones de la brigada de Trípoli de Sam Najjair. El libro es el diario de un ciudadano libio irlandés que participó en la liberación de Trípoli del dominio de Gaddafi en el verano del 2011, durante la guerra civil libia. El lector sigue al personaje principal de Dublín a Trípoli y luego de vuelta a Dublín, al final de la guerra. En el libro, dirigido ante todo a la población irlandesa con el propósito de conseguir su apoyo a la revolución, Sam Najjair esboza un espacio intercultural entre Irlanda y Libia, aportando una 'perspectiva irlandesa' al conflicto libio a través de su doble identidad de inmigrante libio de segunda generación establecido en Irlanda.

Palabras clave. Irlanda, Libia, interculturalidad, autobiografía, brigada de Trípoli, Sam Najjair.

We, here in our internment camp, greet the 1st September revolution and its leader, Colonel Mu'ammar al-Qhadafi. The voice of this leader reaches us despite the solitary confinement cells and the prison guards. [...] Long live the Arab-Irish struggle.

Libyan radio Voice of the Arab Homeland, 22 December 1976

This message of support for Muammar Gaddafi's pan-Arab and quasi-socialist aspirations emanated in 1975 from republican prisoners in the Maze prison in Northern Ireland.
It was read on the official Libyan radio Voice of the Arab Homeland one year later, as part of the propaganda celebrating the anti-imperialist convictions of the Libyan regime a few years

ISSN 1699-311X 
after Gaddafi came into power following the 1969 coup against King Idris. ${ }^{1}$ Simultaneously with the radio announcement, An Phoblacht, the Irish republican newspaper, was publishing extracts from Gaddafi's Green Book promoting his model of direct popular democracy, based on the participation of grassroots popular committees. ${ }^{2}$ The striking contrast between the republicans' enthusiasm shortly after Gaddafi seized power in the 1970s and the general discredit at the moment of his fall in 2011 resulted from a reign associated with despotism, corruption and widespread oppression of the people.

In Soldier for a Summer, Irish Libyan Sam Najjair gives a detailed account of his participation in the Libyan revolution against Gaddafi in 2011, while making a point of explaining his motives to the general public, in particular to Irish readers. In the narrative, he conjures up the memory of the republican commitment of his Irish grandparents to antiimperialism. After 40 years of the Gaddafi dictatorship, the republican ideal was intact but the old Libyan ally had become an enemy to destroy. Comparisons between the Irish struggle to obtain independence from Britain and conflicts in the Arab world have been commonly deployed by militants since the end of the 1960s (Louvet 2016), but one striking feature in Sam Najjair's autobiographical work is the extent to which interculturalism pervades the narrative of the man born in Ireland to an Irish mother and a Libyan father.

Interculturalism results from an interaction between different cultures and announces the possibility of the emergence of a new form of cultural expression and identity. As such, interculturalism can be observed in particular as an outcome of immigration, with the second generation of immigrants being steeped in two cultures and trying to reconcile them in the narrative of the self to build a sense of identity.

1. King Idris was receiving medical treatment in Istanbul when military officers proclaimed the republic and Gaddafi became Chairman of the Revolutionary Command Council in September 1969.

2. The Green Book was published in 1975 and translated into English in 1976. See 1976. "A Government by the People: Gadaffi's vision of Direct Democracy", An Phoblacht, 20 February, p.3.
In the case of second-generation immigrants, autobiographical narratives are written testimonies of the process of conciliation and reconciliation at play in "minor literature" in the words of Deleuze, that is to say emerging from a minority living among a majority culture and whose main three characteristics are the deterritorialization of the language, the connection of the individual and the political and collective arrangement of utterance (Deleuze and Guattari 1996: 29-33). Such characteristics are at play in Soldier for a Summer as the reader follows the narrator from Dublin to Tripoli and then back to Dublin at the end of the war.

Throughout the narrative, Sam Najjair outlines an intercultural space between Ireland and Libya, opening 'an Irish angle' on the Libyan conflict, directly connected to his dual identity as the son of a Libyan immigrant living in Dublin. The Irish angle, which will be analysed in this paper, provides legitimacy to the fight in Libya while soliciting empathy and understanding from the Irish reader. It can be identified as being part of what the political sociologists Keck and Sikkink call "framing" the issue, that is to say shaping the narrative in such a way that it is likely to rally support for a cause, often by making use of symbolic references which are immediately identified by the target audience (Keck and Sikkink 1998: 10). There is no literary, political or academic writing explaining a revolution such as the one which took place in Libya which was not "framed" by the author. Explaining necessarily involves defending a perspective on the one hand and trying to engage with the target audience on the other.

At the outset of this article, I will look at the political context enveloping the end of Gaddafi's rule in 2011 and Irish media coverage of Irish participation in the Tripoli brigade, the militia in which Najjair fought and which was instrumental in the liberation of Tripoli from Gaddafi's army. In the second part of the article, I will focus on Najjair's work in order to analyse his framing of the Libyan conflict, with a particular emphasis on intercultural references.

\section{Intermingled histories}

\section{A) A Winter of Discontent}

Gaddafi had been in power for 42 years when 
Sam Najjair's narrative started in February 2011, at a time when demonstrations against his regime, which began in January 2011, were being violently suppressed, in particular in Benghazi, the eastern epicentre of the revolution. ${ }^{3}$

Inspired by uprisings in Tunisia and Egypt, protesters from all walks of life were progressively gaining ground against Gaddafi's loyalist army and African mercenaries in the east of Libya, at the cost of severe repression. On 15 February, the army violently suppressed demonstrators on the streets of Benghazi. They were protesting against the arrest of Fathi Terbil, a lawyer defending the families of 1,270 convicts in Abu Salim jail who had allegedly been killed in 1996 by the regime security forces. ${ }^{4}$ Two days later, on 17 February, which was declared a "Day of Anger" by protesters, the army opened fire on demonstrators, killing several hundred people. ${ }^{5}$ The violent suppression of demonstrations increased the unpopularity of the regime within the population but also within the political class and ministers started to resign, including key figures such as the Interior Minister Mustafa Abdul Jalil and Justice Minister Abdul Fatah Younis. ${ }^{6}$ A National Transitional Council (NTC) was set up in Benghazi in February 2011 under the command of several rebel leaders. ${ }^{7}$

Support from the international community in favour of the rebellion was unqualified. On 17 March, the United Nations Security Council passed a resolution calling for a ceasefire to protect civilian population and to allow the military intervention of an international coalition

3. Jansen, Michael. 2011. "Libyan forces take action against demonstrators", Irish Times, 17 February.

4. Fitzgerald, Mary. 2011. "Benghazi women still seek their 'disappeared", Irish Times, 3 March.

5. Jansen, Michael and Fitzgerald, Mary. 2011. "Up to 300 protesters shot dead in Libya", Irish Times, 21 February.

6. 2011. "Gaddafi loses more Libyan cities", Al Jazeera, 24 February, http://www.aljazeera.com/ news/africa/2011/02/2011223125256699145.htm

7. Emerson, Newton. 2011. "Powerful names to conjure with in Libya's transitional council", Irish Times, 24 August 2011. which started on 19 March (UNSC resolution $\mathrm{n}^{\circ}$ 1973, 17 March 2011, S/RES/1973). Rebel forces gradually gained more and more territory and strategic positions like Misrata airport in May 2011. ${ }^{8}$ At the start of July, when Sam Najjair joined the fight in Libya, a rebel offensive was being launched from the south of the country, the Nafusa Mountains, towards the north and the capital Tripoli, a city with huge symbolic value. ${ }^{9}$ August witnessed the fall of Tripoli to the rebels along with Gaddafi's headquarters, an action which is outlined in detail by Najjair in his account. On 16 September, the UN acknowledged the official status of the NTC whose President, Mustafa Abdul Jalil declared later that the revolution led to 25,000 deaths over eight months. ${ }^{10}$ Finally, on 20 October 2011, Gaddafi was tracked down and murdered in Sirte; Libya was declared to be a liberated state by the NTC on 23 October 2011. Najjair's account ends in November, with general enthusiasm regarding Libya's democratic future.

The role of social media and internet platforms such as YouTube in contemporary transnational activism is particularly well described in Najjair's narrative. With great honesty, Najjair acknowledges the fact that when he was a younger man, he used to think Gaddafi was a "necessary evil" for his country, keeping it a united political entity and ensuring its wealth thanks to a systematic exploitation of oil (Najjair 2013: 6). Gaddafi made a point of defending Libya's international prestige and pride based on pan-Arab - and then panAfrican - ambitions inspired by the Egyptian president Gamal Abdel Nasser. ${ }^{11}$ In 2011,

8. 2011. "Rebels take control of Misrata airport", Irish Times, 11 May.

9. On $29^{\text {th }}$ June 2011 France admitted to sending weapons to the Libyan rebels in Nafusa mountains, South West of Tripoli, see 2011. "Une commission $\mathrm{du}$ Sénat américain autorise l'intervention américaine en Libye", Le Monde, 29 June.

10. Mustafa Abdul Jalil, the NTC President, met Barack Obama and claimed 25000 Libyans had died during the 8 month revolution, see Bordenet, Camille. 2014. "La lente désintégration de la Libye post-Kadhafi”, Le Monde, 26 August.

11. In 2006, Gaddafi declared himself King of Kings of Africa, see 2011. "A tyranny ends", Irish Times, 21 October. 
Najjair was exposed to the events in Libya via the internet, by reading testimonies and watching videos posted by actors in the field, almost immediately after the events they recorded took place. Najjair has vivid memories of the first video clips he saw of the revolution, such as the toppling of Gaddafi's statue in Tobruk, in East Libya, by an excited crowd (Najjair 2013: 13). At this point, he was still an observer in an internet café in Ireland and, as an independent thinker, he comments "Brave, brazen or just crazed with excitement? I wasn't sure". But the constant exposure to images and testimonies from the internet fuelled his indignation and erased the geographical distance. Two occurrences convinced Najjair he did not have a choice but to go to Libya to help his people: acts of bravery performed by Libyan rebels against Gaddafi's regime and atrocities committed by loyalist military troops. In his narrative, Najjair makes a point of naming some of the men who contributed to his taking part in the Libyan revolution, who inspired him with their heroic actions, people like Mahdi Zeyo, ${ }^{12}$ Mohamed Nabbous and Ali Obeidi (Najjair 2013: 9-11). The final straw that motivated his departure was the news that some loyalist mercenary troops were using rape as a weapon of war. ${ }^{13}$ At this point, Najjair made up his mind. As Ron Eyerman defended in "How social movements move" (Eyerman 2005: 42), emotions, like the feeling of injustice, can be one of the motives of political actions and the aim of social movements is to "create, organize, direct and channel collective emotion in particular directions, at particular targets", here in the fight against the Libyan regime in power. Najjair describes his wish to go help liberate Libya as a "pull", an urge which he explains in particular by his first-hand experience

12. See Fitzgerald, Mary. 2011. "One man's sacrifice that helped free Benghazi from Gadafy", Irish Times, 2 March.

13. Najjair also mentions rape in the case of Ireland under British rule at the start of the 20th century: "There was one story about Bill walking into a pub and shooting an English officer who had raped a girl he knew. (These stories came back to me very strongly when I encountered for myself brutality in the Gaddafi regime)" (Najjair 2013:15). of "Libyan culture and Islamic values", in other words the cultural and religious factors that allowed his close identification with the Libyan people and the moral duty to take action as the result of a conscience dilemma (Najjair 2013: 11). The sincerity of Najjair's introspection, and the point he makes of rationally understanding the reasons that motivated his own actions, give a unique value to his testimony.

\section{B) The Tripoli Brigade}

The Tripoli revolutionary brigade, in which Sam Najjair fought, was one of the biggest rebel units in Libya and the first to reach the capital and fight for its liberation in August 2011. The leader of the Tripoli revolutionary brigade was another Irish-Libyan, Mahdi alHarati, Najjair's brother-in-law. Al-Harati's family had left Libya for Egypt following persecution by Gaddafi's regime on religious grounds (Najjair 2013: 7). For 20 years, he lived in Ireland where he met his wife Eftaima, Najjair's sister, with whom he had four children. He became an Irish citizen and an Arabic teacher in Dublin. ${ }^{14}$ When in Ireland, al-Harati was active in pro-Palestinian activism. ${ }^{15} \mathrm{He}$ is the person who rallied foreign fighters around him to form the Tripoli brigade, from about 15 originally, to about 600 in 2011. ${ }^{16}$ Very prominent among the revolutionaries, he became deputy leader of the Tripoli Military Council after the fall of Tripoli, under Abdel Hakim Belhaj, the leader of the Libyan Islamic Fighting Group. ${ }^{17}$ Later, in August 2014, he was elected the first Mayor of Tripoli since the revolution had taken place. ${ }^{18}$

14. Fitzgerald, Mary. 2011. "Dublin man denies receiving funds from US to assist overthrow of Gadafy", Irish Times, 22 November.

15. Al-Harati took part in the 2010 international flotilla challenging the Gaza blockade; see "Irish citizen 'beaten' by Israeli forces", Carbery, Genevieve. 2010. Irish Times, 9 June.

16. Najjair counts 600 members of the brigade at the start of August and 1,400 for the whole period (Najjair 2013: 97 and 291).

17. Islamic armed group active against Gaddafi's regime between the mid 1990s and 2011.

18. 2014. "Irish-Libyan elected mayor of Tripoli", Irish Times, 7 August. 
The Tripoli brigade was formed and based outside of Tripoli but was very deliberately composed largely of former residents of the city to ensure that, when they entered the city, they were seen as liberators and not as 'outside' invaders. The specificity of the brigade was to have a large number of expatriates who returned to Libya to free the country from Gaddafi's rule. That particular feature meant that one could find different degrees of religiosity as well: jihad was a motivation for some with the idea of becoming a martyr and being protected by Allah, but others were primarily concerned with liberating the country from a dictator (Najjair 2013: 54). Najjair designates patriotism and solidarity with his people under oppression as the main incentives that led him to Libya but he also relates his spiritual and religious experience on the ground.

The members of the brigade received military training before heading for the northern and western provinces. That part of the narrative is extremely important because it serves as a transition before the actual fight, as well as a trial to test the future fighter's resilience. The recruits of the brigade were not professional soldiers but stonemasons, doctors, businessmen, mechanics, web designers, teachers, etc. ${ }^{19}$ When Najjair arrived at the brigade in July, he became number 329, meaning he was the $329^{\text {th }}$ person to join the brigade which had already been training for about a month (Najjair 2013: 53). The account of his one-month training is that of an ordeal, characterized by physical and moral strain quite often, but also by satisfactions as with the revealing of one's potential to be helpful in a situation of war, learning the use of weapons, especially sniper guns, and the crucial feeling of comradeship with fellow combatants. Looking back, the sense of unity, despite the different backgrounds in the brigade, which stems from having "a common purpose and a shared enemy" is what Najjair appreciated most in the campaign (Najjair 2013: 54). He also underlines the fact that the men were all treated as equals in the brigade. That is a good illustration of horizontal or peer bonding between fighters, which is considered by social

19. 2011. "Irish Libyans join rebels trying to oust Gadafy", Irish Times, 13August. researchers to be part of the primary group cohesion, with both an affective side and an instrumental side (Griffith 1988). That cohesion is one of the conditions for success, in particular where secondary group cohesion is not as clearly defined as in traditional $\operatorname{armies}^{20}$ (Siebold 2007).

\section{B) The Irish Press and Foreign Fighters in the Libyan War}

The presence of a handful of Irish citizens in Libya, or Libyan residents in Ireland, was widely covered in the Irish press. Interest among the public was strong and the press devoted much more space to the issue than one could have imagined it would, given the small number of Irish fighters in the Libyan conflict. Al-Harati and Najjair were interviewed on several media. On television, they were guests of the very popular Late Late Show (RTE 1, 9 September 2011) and they were interviewed on RTÉ, the national broadcaster. ${ }^{21}$ In Soldier for a Summer, Najjair relates his interview with Belfast journalist Michael Gregory, that resulted in the publication of the article "The Irishman who swapped Dublin nightlife for the Libyan frontline". Gregory told him "I'm going to make you famous back home, man" which turned out to be partly true as Najjair received considerable publicity (Najjair 2013: 137). He is now regularly interviewed as an expert of the political situation in Libya and Syria. $^{22}$

A review of the Irish printed press indicates an emphasis on the idea that the participants in the Libyan war were like the man on the street in Ireland. The general message from the Irish press was that the rebel fighters in Libya were like ordinary members of Irish society, with

20. Secondary cohesion is made up of "organizational bonding" between personnel and their next higher organization (like a battalion), and "institutional bonding" between personnel and their military branch (like the army)

21. For example, RTE radio 30 August 2011; Interview in RTE Morning edition, 10 September 2013, etc

22. For example interviews on TV3 Ireland The Morning Show, 29 September 2013; Newstalk, 4 September 2013; RTE Radio The Late Debate, 17 June 2014; France 24 English 12 March 2014, etc. 
the same codes of reference and the same cultural values. This is particularly striking in the Irish Times in several articles by Mary Fitzgerald, special correspondent in Libya. ${ }^{23}$ In an article characteristically entitled "It has changed me...I used to be a normal Irish guy", ${ }^{24}$ she mentions the Irish accents of some members of the Tripoli Brigade: "There are several Irish-inflected accents in the room. The brigade includes men who have lived and worked in Dublin, among them a software engineer and a psychiatrist". ${ }^{25}$ Those men were not typical soldiers. On the contrary, not only did they live in Ireland, but they were also portrayed as part of Irish society with solid jobs in Dublin and were integrated in the community. Similarly, Fitzgerald mentions a humorous remark that she attributes to an American fighter in the brigade who said: "It's almost an Irish revolution". ${ }^{26}$ The light tone allows one to draw a parallel between the revolution in Libya and Irish history, thus appealing to the reader's sympathy. The amateur nature of the Irish fighters in the Tripoli Brigade is also underlined in the Irish Independent in an article whose tell-tale headline is "The Irish family which took up arms to overthrow a despot". ${ }^{27}$ The article portrays Kareem Salam, a Libyan citizen based in Galway. The journalist comments: "Just a year ago he was at the Electric Picnic". The Electric Picnic is an iconic Irish music festival that gathers throngs of young people from all over Ireland every summer. This pointed reference to Salam's rapid progression from average Irish youth to rebel fighter in Libya emphasized the 'normality' of those committed to the struggle against Gaddafi. Likewise, the idea that fighters in the Tripoli Brigade could be someone the reader would come across on the street in Dublin is used by The Independent

23. Sam Najjair thanks Mary Fitzgerald at the end of his book for "keep[ing] the cause and efforts alive to fellow Irish people" (Najjair 2013: 290).

24. Fitzgerald, Mary. 2011. "It has changed me...I used to be a normal Irish guy", Irish Times, 30 August.

25. Ibid.

26. Ibid.

27. 2011. "The Irish family which took up arms to overthrow a despot", Irish Independent, 27 August. news editor Don Lavery to describe Najjair in "The Dubliner who fought Gadaffi": "It was a transformation that saw Housam 'Sam' Najjair, an Irish-Libyan, move from playing the 'Call of Duty' computer game in Dublin to becoming a deadly sniper in the Libyan revolution in 2011". ${ }^{28}$ Here again, the mention of "Call of duty", a well-known cultural reference, allows the journalist to portray Najjair as just one among many Irish computer game players. ${ }^{29}$

There are two sides to the view generally projected by Irish press that some men fighting in Libya are exactly the same as the next Irishman. First of all, there is something sensational in the revelation that an 'average' person could abandon his everyday life and security in a country such as Ireland to take up a gun to liberate his country from the claws of a dictator. That is certainly a story that could sell newspapers and appeal to readers. But beyond that, the tone of the articles also encourages identification from Irish readers and thus enjoins support for the Libyan rebels. In the creation of collective identities, which, according to the definition given by Goodwin, is a cognitive process demarcating "them and us", the media have a strong role to play as to where to draw the boundary between two groups in the collective mind of public opinion (Goodwin, Jasper and Polletta 2001: 8). Some Irish-Libyan rebels were putting their lives at risk every day at the time the articles were published and the Irish press highlighted that they were not all $\mathrm{Al}$ Qaeda Islamists longing to die as religious martyrs, as Gaddafi was asserting in his anti-rebel propaganda. ${ }^{30}$ Such extreme Islamists with fundamentalist values would hardly be understandable to a Western audience and this was not the image favoured by the Irish media which, in practice, rejected Gaddafi's claims. The rebel fighters from Ireland, in particular, were constructed as "ordinary" Irishmen who made the "extraordinary" choice to risk their lives on the battlefield.

28. 2013. "The Dubliner who fought Gadaffi", Don Lavery, The Independent, 7 September.

29. Before heading to Libya, Najjair was a construction worker in Dublin.

30. Jansen, Michael. 2011. "Libyan leader blames al-Qaeda for uprising”, Irish Times, 25 February 
This perspective on foreign fighters in the Tripoli Brigade is also very much what appears in Najjair's account, in which the apprenticeship of war in Libya is vividly described in a narrative that starts and finishes in Ireland.

In the second part of this article, I will focus on the many ways in which interculturalism impregnates Najjair's account of his fight in Libya.

\section{The "Irish Angle" on the Libyan Conflict}

\section{A) Pervasive Ireland}

One of the striking features when you first look at Najjair's book is the extra textual information that associates the Libyan events with Ireland. The very title of the book, Soldier for a Summer: One Man's Journey from Dublin to the Frontline of the Libyan Uprising, emphasizes the amateur nature of the soldier in question and also the idea of a travel, of an initiatory trip being taken from the safety of the Irish capital to the Libyan battlefield, with something of an epic quality to it. What is more, the two introductory quotations of the text are references to Irish mythology and national heroes:

They shall be spoken of among their people; The generations shall remember them,

And call them blessed;

But I will speak their names to my own heart In the long nights....

(from 'The Mother' by Pádraig Pearse)

'It is little I would care', said Cuchulain, 'if my life were to last one day and one night only, so long as my name and the story of what I had done would live after me.'

(from Cuchulain of Muirthemne by Lady

Augusta Gregory)

The quotations are part of a reflection on posterity and sacrifice. Instead of quoting Homer, for example, Najjair chose Irish mythology, a reference he has shared with Irish readers since childhood, allowing them to relate to the story which is going to be told. This helps to situate a text dedicated to the Libyan revolution in an Irish context. Geographical indications, which are present at the very start of the account, further anchor the book in an Irish context, in South Dublin, to be precise. The explicit geographical indicator "October 2011, Portobello, Dublin" precedes the very first paragraph in which Najjair depicts himself as a survivor, back in his flat in Portobello after four months spent on the battlefield in Libya. The opening paragraph itself refers to Irish emblematic writers and specific geographical locations; he includes a description of the Chatterbox Café, near 'Portobello Road' (actually South Richmond Street), in Dublin, where men of the Libyan community in Dublin used to meeting over coffee to check the internet: "The atmosphere was always light-hearted and easy-going - at least it was until February 2011. When the Arab Spring erupted in Libya and some demonstrators flared up in the East of the country, all that changed... 'changed utterly', as Yeats put it" (Najjair 2013: 5).

The narrative is shrouded in an Irish aura. Interculturalism, in the sense of an overlap between cultures, is not only obvious but purposeful. It also impregnates the self-portrait of the author in his autobiographical narrative.

\section{B) An Irish Man}

Najjair was born in Dublin and grew up in Rathfarnham. He has a Dublin accent and pale complexion compared to those of fellow Libyans, as is underlined several times in the narrative. His father is a Libyan citizen who immigrated to Ireland as a student in the 1970s and then ran a business selling handbags. His mother is an Irishwoman from Blackrock, county Dublin. ${ }^{31}$ She is the daughter of Geoffrey Golden and Maire O'Donnell, two famous Abbey Theatre actors whose photographs feature in the book. She converted to Islam when she met her husband while in her twenties. There is a republican background in the family, which Najjair sees as a tradition of fighting against an unfair ruler, and of which he is particularly proud. This interpretation can be noted in the way he depicts his grandmother:

She used to tell me stories about Irish history, the fight against British rule in Ireland, and about her father, Bill O'Donnell, who had been a member of the Tipperary Brigade in the 1920 's. His father, my great-great grandfather, was a quartermaster for Pearse Buchanan's brigade in the early days of the Irish Republican

31. "The Irish family who took up arms to overthrow a despot”, Irish Independent, 27 August 2011. 
Army. Even though the area around Cashel where the family lived was loyalist, some of my family were well-known IRA activists. [...] Gra Wa once featured in the 'Fiche Ceist' series in one of the national newspaper. She was asked, 'If you could change one thing about the world, what would it be?' /She answered, 'I'd want a united Ireland.' $/$ That always impressed me (Najjair 2013: 15-6).

One interesting feature here is that the term "brigade" designates both Najjair's forefathers' militia units in the Irish War of Independence (1919-1921) and his own militia unit, the Tripoli Brigade. The Tipperary Brigade was part of the Irish Republican Army during the Irish War of Independence and was active in Munster. The interwoven reference to Irish and family history and the fight against British imperialism which involved Najjair's greatgreat-grandfather, his great-grand-father and his grandmother, gives a particular meaning to his own involvement in Libya. Fellow rebels in Libya are depicted as freedom fighters just as his Irish ancestors were.

The Libyan war was the opportunity for Najjair to reconcile his Irish and Libyan identities, taking a stand against imperialism as his Irish ancestors had done and defending his father's country:

My life had been trapped between opposites. I was Sam, I was Housam; I was Irish and Libyan; Western, Muslim; father, childless; partnered, single; good, bad. I needed a showdown between all these opposing forces in my life to achieve some kind of new balance. And then along came the revolution- Libya's chance to sort out its problems, and my chance to do the same (Najjair 2013: 38).

Quite symbolically, Najjair arrived in Tunisia showing his two passports to the customs officers, a Libyan passport and an Irish passport.

\section{C) Conflicted Identity}

Throughout the narrative, Najjair identifies himself as split between two identities: his Libyan self "Housam" and his Irish self "Sam", the latter short for Housam and much more ordinary-sounding in Ireland. Regarding the period he spent as a young man in Ireland, before heading to Libya, he writes:

I went out a lot, and hung about a lot with my Irish friends. You could have taken me for being no different to them, and sometimes I almost thought I was no different - I was Sam. But there was always something that separated me. I could be out with them for the whole weekend, for example, having a great time, everybody's pal, but then when it came to the big soak-up full Irish breakfast on Sunday morning and I would refuse to eat a sausage, it was as if I was an alien again, I was Housam (Najjair 2013: 25-6).

Here he is perceived as being almost irretrievably alien despite shared experiences. Within the narrative, Najjair describes periods of time when he feels closer to Islamic values, self-discipline and rigour, and other times when he leads the carefree life of any Irish youth, what he considers to be living in the Dublin fashion. Najjair explains the process when comparing the different lifestyles he had as a teenager in Libya and in Ireland, considering that "through secondary school and puberty, [he] went from being a wellbehaved thirteen-year-old Muslim boy to a tough, streetwise sixteen-year-old Dubliner" (Najjair 2013: 23). Najjair knows that some of the Islamic values he shares are in opposition to what he calls "Western" culture (Najjair 2013: 38). For instance, he is very lucid in his belief that his admiration for martyrs such as Mahdi Zeyo, who drove a car filled with gas canisters and gunpowder at full speed against the gate of a Libyan loyalist base, cannot be understood in Ireland: "I realised that Mahdi Zeyo - a man who by all accounts loved life would be seen by some, especially in the West, as having some kind of death wish. [...] He did a very brave thing" (Najjair 2013: 9). Even with members of the Libyan community in Dublin, difficulties communicating about the revolution would arise, especially among those who had spent little time in Libya and did not speak Arabic. According to Najjair, they did not feel the same urge to fight in Libya after viewing images of atrocities on the internet, believing, for example, that one could only have religious reasons to join the revolution and, hence, one had to be a conservative: "Some of the young Libyans in Dublin had the misguided idea that you had to be religious to join the fight or be old-fashioned to fit in with it" (Najjair 2013: 11).

\section{D) Intermingled Histories}

To explain the Libyan revolution to his Irish 
readers, Najjair sometimes used comparisons with Irish resistance against British occupation. This allowed him to reconcile his Irish and Libyan identities and to enlist the reader's sympathy for the cause of the Libyan revolution. Several examples may be quoted. It is the case, for instance, when explaining the undermining of the Berber culture under Gaddafi (Chaker and Ferkal 2012) "Ironically, Gaddafi had tried to eliminate the Berber culture from Libya in a way similar to the British attempts to eliminate Irish culture from Ireland. Irish culture had survived and hopefully Berber culture will reassert itself in Libya" (Najjair 2013: 50) - or, again, about the need to accept sacrifice. Irish history is used an example to show that sacrifice is necessary in defence of the national interest and the people's sovereignty. It had to be explained in a way that Irish people would relate to and it also had to be dissociated from Islamist terrorism. When Najjair endeavours to explain why his own Irish mother would have been proud if he had died fighting (Najjair 2013: 49), he makes a comparison with the Easter Rising in Ireland:

I know a lot of people will find this attitude hard to understand but maybe a good comparison is with that of the mothers of the Irish revolutionaries in 1916. Think of their hearts aching at the thought of what the British would do to their sons, but also their pride in what their sons had done for their country (Najjair 2013: 46).

The Easter Rising is a foundation event in Irish history, during which the Proclamation of the Republic was read for the first time by Patrick Pearse, who declared the right of the people of Ireland to the ownership of Ireland against the occupation of a foreign ruler, Britain. Following the insurrection, most of the leaders who proclaimed the Irish Republic as a sovereign independent state, among them Patrick Pearse and James Connolly, were executed by the British army and became national martyrs and inspirational heroes of the Irish struggle for independence. It is explicitly suggested that the part Najjair and his brothers in arms played in liberating Libya must be seen as in the line with what freedom fighters achieved in Ireland at the time of the War of Independence:

Just as Ireland went through the War of Independence and Civil War in the early twentieth century, so Libya is going through its own troubled times, and just as thousands of young Irish men and women, including a few of my own ancestors, were swept up to Ireland's struggle for freedom from British rule, in $2011 \mathrm{I}$ found myself playing a part in Libya's upheaval against an oppressive regime (Najjair 2013: 267-8).

It is not only the literary and mythical dimensions of Ireland which are used as a background to the narrative of the Libyan conflict, but also its foundation events together with the general patriotic fondness for leading figures from the War of Independence. This is the cultural background which conjointly belongs to Najjair and his fellow Irish countrymen and through which they can relate together in understanding a distant country such as Libya. The writer comes to the assistance of the fighter in his efforts to bridge a gap between Libya and Ireland so that Irish nationals understand the desire to overthrow the tyrant Gaddafi, even if lives are lost in the process, for the good of the Libyan nation. The "Irish angle" on the Libyan conflict derives from the dual identity of the author and his wish to underline the continuity between Irish values of resistance against colonialism and his fight in Libya. The framing of the narrative of the Libyan conflict ensures it is understood as he believes it should be by the Irish audience.

Soldier for a Summer is a unique first-hand testimony of a Dubliner who lives now with a piece of shrapnel from Libya in his leg, and in his mind the conviction that he is following in the footsteps of his Irish forefathers (Najjair 2013: 206). The cult of resistance against all forms of oppression and the belief in the people's sovereignty is what allows interculturalism to pervade the narrative, despite the very different historical and geographical contexts of Libya and Ireland. The main challenge of the book is that Irish readers understand the battle for justice that was led by Irish rebels against Gaddafi, maybe even to identify with those fighters, and the intercultural bridges which are built by the author are instrumental in the process. The need to circulate the 'truth' about the Tripoli Brigade is seen by the author as one of the motivating forces in writing this book (Najjair 2013: 287). ${ }^{32}$

32. Interview with Sam Najjair, August 2014. A documentary, "Call of Duty", is currently being ./. 
Najjair's autobiography contributes to an understanding of interculturalism because his insight reveals the active role of the subject in creating his own dual identity, based on a conscious or unconscious selection of features characterizing the two places of origin. Indeed, the intercultural self-portrait which appears in Soldier for a Summer is a creation of the writer and results both from his own perception of Irish and Libyan cultures and his wish to pose as the personification of the two cultures brought together by the notion of resistance against an unfair rule, be it in the past against the British Empire for Ireland or in the present days against the dictatorship of Gaddafi for Libya. The book also shows that the compatibility between Irish and Libyan cultures is bound to have limits, with occurrences when the narrator experienced momentary feelings of inadequacy in Ireland, often due to Islamic rules preventing him from acting exactly like any other Irish youth. What is more, Najjair's narrative underlines the fact that his experience of interculturalism has not been homogenous over the years but has included times when he felt closer to Libyan culture - which he associates with periods when he experienced stronger religious feelings

\% made from the book with Ruan Mágan as a director.
- and times when his lifestyle was closer to secular western culture. It is worth mentioning that Catholicism, which has played such a crucial role in shaping contemporary Irish society, is hardly mentioned in the book and never underlined by the narrator as a major factor in his perception of Irishness.

The epilogue of Soldier for a Summer introduces briefly the current political situation in Syria and mentions the involvement of some of the Libyan rebels in Liwa al-Umma, a militia which was founded by Mahdi Al-Harati in 2012 to fight the Assad regime. ${ }^{33}$ Najjair, who participated in the training of local paramilitary groups in Syria, emphasises the intricacy and violence of the current political situation in Syria, before hinting that it might be the topic of a second book. Given the current European and American policy of regarding the return to the national territory of fighters from Syria as a possible security threat, especially following the Paris attacks (13 November 2015), Najjair's second book will be a renewed challenge for the activist to explain his commitment and for the writer to reach his audience.

33. Fitzgerald, Mary. 2013. "Tanaiste concerned about Irish citizens fighting with rebel forces in Syria", Irish Times, 27 June.

\section{Works Cited}

Primary Sources

\section{Sam Najjair}

Interview with Sam Najjair, August 2014.

Soldier for a Summer, Sam Najjair, Hachette Books Ireland, Dublin, 2013.

Sam Najjair's interview, Late Late Show, RTE 1, $9^{\text {th }}$ September 2011.

Sam Najjair's interview, RTE radio 30 ${ }^{\text {th }}$ August 2011.

Sam Najjair's interview, RTE Morning edition, $10^{\text {th }}$ September 2013.

Sam Najjair's interview, TV3 Ireland The Morning Show, $29^{\text {th }}$ September 2013.

Sam Najjair's interview, Newstalk, $4^{\text {th }}$ September 2013.

Sam Najjair's interview, RTE Radio The Late Debate, 17 $7^{\text {th }}$ June 2014.

Sam Najjair's interview, France 24 English $12^{\text {th }}$ March 2014.

\section{Libya}

Voice of the Arab Homeland, Libyan radio, Tripoli, 22 ${ }^{\text {nd }}$ December 1976.

UNSC resolution $n^{\circ} 1973,17^{\text {th }}$ March 2011, S/RES/1973.

Gaddafi, M, 1976. The Green Book.

\section{Irish Press}

“Irish citizen ‘beaten’ by Israeli forces”, Genevieve Carbery, Irish Times, $9^{\text {th }}$ June 2010. 
"Libyan forces take action against demonstrators", Michael Jansen, Irish Times, $17^{\text {th }}$ February 2011.

"Up to 300 protesters shot dead in Libya", Michael Jansen and Mary Fitzgerald, Irish Times, $21^{\text {st }}$ February 2011.

"Libyan leader blames al-Qaeda for uprising", Michael Jansen, Irish Times, $25^{\text {th }}$ February 2011.

“One man's sacrifice that helped free Benghazi from Gadafy”, Mary Fitzgerald, Irish Times, 2nd March 2011.

"Benghazi women still seek their 'disappeared"”, Mary Fitzgerald, Irish Times, $3{ }^{\text {rd }}$ March 2011.

"Rebels take control of Misrata airport”, Irish Times, $11^{\text {th }}$ May 2011.

"Irish Libyans join rebels trying to oust Gadafy", Irish Times, 13 ${ }^{\text {th }}$ August 2011.

"Powerful names to conjure with in Libya's transitional council", Newton Emerson, Irish Times, $24^{\text {th }}$ August 2011.

"The Irish family which took up arms to overthrow a despot”, Irish Independent, $27^{\text {th }}$ August 2011.

"It has changed me...I used to be a normal Irish guy", Mary Fitzgerald, Irish Times, 30" August 2011.

“A tryranny ends", The Irish Times, 21st October 2011.

"Dublin man denies receiving funds from US to assist overthrow of Gadafy", Mary Fitzgerald, Irish Times, $22^{\text {nd }}$ November 2011.

"Tanaiste concerned about Irish citizens fighting with rebel forces in Syria", Mary Fitzgerald, Irish Times, $27^{\text {th }}$ June 2013

“The Dubliner who fought Gadaffi”, Don Lavery, The Independent, $7^{\text {th }}$ September 2013.

"Irish-Libyan elected mayor of Tripoli”, Irish Times, $7^{\text {th }}$ August 2014.

\section{Irish Republican Press}

“A Government by the People: Gadaffi's vision of Direct Democracy”, An Phoblacht, $20^{\text {th }}$ February 1976, p.3.

\section{International Press}

"Gaddafi loses more Libyan cities", Al Jazeera, 24 $4^{\text {th }}$ February 2011 http://www.aljazeera.com/news/africa/2011/02/2011223125256699145.html

"Une commission du Sénat américain autorise l'intervention américaine en Libye", Le Monde, $29^{\text {th }}$ June 2011.

"La lente désintégration de la Libye post-Kadhafi”, Camille Bordenet, Le Monde, 26 ${ }^{\text {th }}$ August 2014.

\section{Seconday Sources}

Chaker, Salem and Ferkal, Masin. 2012. "Berbères de Libye: un paramètre méconnu, une irruption politique inattendu", Politique africaine 125.105-26.

Deleuze, Gilles and Guattari, Félix. 1996. Kafka. Pour une littérature mineure. Paris: Editions de Minuit.

Eyerman, Ron. "How social movements move, Emotions and social movements", in Flam, Helena and King, Debra (eds.). 2005. Emotion and Social movements, Abingdon: Routledge.

Goodwin, Jeff, Jasper, James M. and Polletta, Francesca (eds.). 2001. Passionate Politics: Emotions and Social Movements. Chicago: The University of Chicago Press.

Griffith, James. 1988. "Measurement of Group Cohesion in U.S. Army Units", Basic and Applied Social Psychology 9.2. 149-71.

Keck, Margaret E. and Sikkink, Kathryn. 1998. Activists Beyond Borders: Advocacy Networks in International Politics. Ithaca: Cornell University Press.

Louvet, Marie-Violaine. 2016. Civil Society, Post-Colonialism and Transnational Solidarity: the Irish and the Middle East Conflict, Palgrave Macmillan.

Siebold, Guy L., 2007. “The essence of military group cohesion”, Armed Forces \& Society 33.2. 286-95.

Received 27 November 2015 Last edition 16 December 2015

Marie-Violaine Louvet is a Maître de Conférences (Lecturer) at Toulouse 1 - Capitole University. She completed her PhD “L'Irlande et le Moyen-Orient 1967-2013: Lectures domestiques, Discours politiques et Solidarités transnationales" in 2013 at Paris 3-Sorbonne Nouvelle University. She graduated from the Ecole Normale Supérieure de Cachan and is a holder of the Agrégation d'anglais. She is the author of Civil Society, Post-Colonialism and Transnational Solidarity: the Irish and the Middle East Conflict (Palgrave Macmillan 2016). 